solution of the problem of smoke pollution. Yet this problem in industrial and sanitary reconstruction will have to be faced when peace comes, and for that reason it seems unfortunate that the Local Government Board Committee on Smoke Abatement should have indefinitely postponed its meetings on the outbreak of war. J. B. C.

\section{METEOROLOGICAL PERSISTENCE.}

THERE is a special sense of appropriateness about the brochure entitled "Konstant auftretende secundäre Maxima und Minima im dem Jährlichen Verlauf der meteorologischen Erscheinungen," by Dr. Eli Van Rijckevorsel, published as No. 102 of the "Mededeelingen en Verhandelingen" of the Royal Meteorological Institute of the Netherlands. For the last dozen years the author has appeared to confine his published scientific activity to the subject of the persistence of secondary maxima and minima in annual meteorological phenomena, and this is his eleventh contribution on the same thesis, the last three of which have received the support of his national institute.

A detailed comparison of the whole series of "tracts" would be necessary to enable us to dogmatise as to the validity of the author's conclusions and the justification of his persistence. There is no doubt, however, that even this eleventh article taken by itself is full of interesting points. A long series of seventy-two years' barometric data from Christiania is dealt with in two thirty-six-year portions, and also as to twentyfive years allocated to sun-spot maxima and twentyfive years to minima in the same period. From the sun-spot point of view, a similar process is applied to shorter periods from Nertchinsk and Innsbruck. The main part of the data, however, consists of daily sums from thirty-three stations in the N. Hemisphere for periods ranging from forty-three years at Haparanda to four at Honolulu and St. Vincent (Cape Verde). The stations are well distributed, five with a mean latitude of $67^{\circ}$ and a range in longitude of nearly $100^{\circ}$; eight with mean latitude $5^{\circ}$, and with gaps in longitude of $120^{\circ}$ for the Pacific and $90^{\circ}$ for the Atlantic; nine with mean latitude $42^{\circ}$, and again a gap of $120^{\circ}$ in longitude for the Pacific; and eleven with mean latitude $2 \mathrm{I}^{\circ}$ in which the Pacific gap is partly bridged by Honolulu. Some of the tables appear to have had a decimal point omitted throughout, and the Honolulu table differs considerably from the others, but the principle of printing sums instead of means, when the periods vary considerably, seems to demand more explanation than the author has given, though this practice has probably been adopted and discussed in one of the ten earlier contributions which are not for the moment at hand.

An excellent series of plates shows the author's idea of the variation with latitude and longitude of the secondary oscillations with which he is dealing, and there is also a comparison of the resulting oscillations from a fifty winters' comparison of Greenwich barometer and thermometer, showing a mean lag of half a week from the barometric maximum to the temperature minimum; a similar comparison in diagrammatic form is given for Bucharest from a fifteen-year period.

Altogether there would appear to be thirty-five oscillations in the year superposed on the ordinary single solar oscillation, but having regard to the classic case of the three "icemen," now so generally discredited in this country, it may be some time before Dr. Rijckevorsel obtains much enthusiastic support among us, for though the reality of the alternations of weather is undeniable, our proverbial traditions nearly all postulate, not the same, but different conditions on a fixed date.

NO. 2508 , VOL. IOO]
THE SHORTAGE OF THE SUPPLY OF NON-PHOSPHORIC IRON ORE. ${ }^{1}$

A LREADY in the pre-war years the supplies of high-class hæmatite to the iron-smelting districts of Europe trom the nearer sources were getting short, and the time was in sight when, for iron ores low in phosphorus such as are required for the production of the "hæmatice grade" of pigiron demanded by those. who make steel by the "acid" process, we shall have either to turn our attention to sources of supply which are less readily accessible, or so to improve metallurgical processes that, from ores which are abundant in closer proximity to the coalnelds, trustworthy substitutes for "Bessemer-grade" acid steels can be economically produced. The thesis advanced by the author of these Howard lectures is that, notwithstanding that the low-grade phosphoric ores of the Englisn Jurassic rocks yield a pig-iron which for steel-making requires refining upon a basic hearth, in Britain the second of the two alternatives mentioned should be chosen.

The subject-matter dealt with in the lectures was assembled under two neads. In the first of the lectures the author presented a conspectus of-the various ironfields where ore production is in progress within the British Isles. In the second he passed in review the various orefields in foreign countries which, under peace conditions, sent produce, either raw or semimanufactured, from their iron mines to supply the British market.

Within the British area there is a remarkable absence of any considerable concentration of iron ore among geological formations of pre-Carboniferous age. The non-phosphoric hæmatites of the Carboniferous Limestone district occur as veins and impregnations, and extend some little distance downwards among these older rocks, but in their distribution they are limited to a narrow belt of country which ranges north and south through the English Lake District and the Forest of Dean, and are probably of post-Carboniferous date. They are less regular in their distribution, and therefore more expensive to exploit, than are the bedded ores associated with the Coal Measures or interstratified in thicker masses among the Jurassic rocks, and the shortage of home supplies of hæmatite has already long been felt.

In former days clay-band and black-band ores, interstratified among the Coal Measures, afforded the main supply of English and Scottish iron, but when steel superseded wrought-iron as the ordinary material for constructional engineering, economic conditions brought about the diminution of iron production from these ores, and though there lie in reserve more than thirty thousand million tons of such ore among our Coal Measures, that source of supply does not at present represent to our ironmasters a national asset which has any great marketable value.

Along the outcrop of the English Jurassic rocks between the coast of Dorset and the Cleveland Hills there is nowhere any lack of low-grade iron ore. In the neighbourhood of the Humber it is the Lower Lias which carries the ore-bed, but generally the Middle Lias is the more prolific horizon. In Northamptonshire the great development of iron ore is in the basal member of the Inferior Oolite series, and at Westbury, in Wiltshire, and throughout the southern counties, the most important development is in association with Corallian rocks. "Just as the Carboniferous is the great repository of Great Britain's fuel wealth, so the Turassic is the bank which holds our fluid reserves of iron ore. The gilt-edged securities of Cumbrian hæmatite are sound, but not unlimited in amount;

1 Abstract of the Howard Lectures delivered before the Royal Society of Arts on April 30 and May 7 hy Prof. W. G. Fearnsides, Sorby Professor of
Geology in the University of Sheffield. 